\title{
The Reconstruction of Tax Treaty In Indonesia
}

\author{
Satria Utama \\ \{msatria@live.com\} \\ Universitas Jayabaya, Jakarta, Indonesia
}

\begin{abstract}
The reduction in tax revenue sources due to tax treaty relates to the reciprocal consequences of differences in tax rates and taxation systems of tax treaty partners. Thus, the tax treaty policy is supposed to be profitable for every country being involved, despite it can lead to unequal income exchange for one of the tax treaty partner countries. This research is a normative juridical research that analyzed secondary data consisting of primary legal materials, secondary legal materials and tertiary legal materials. A qualitative juridical analysis was performed in analyzing secondary and primary data. The results of this study explain that tax treaty policy applied in a country includes the process of initiating the formation of a tax treaty, tax treaty model, negotiation, and termination. In the process of initiating the formation of tax treaty, Indonesia did not have a standard policy or standard operating procedure (SOP) to determine when and how to propose and respond to proposals from other countries regarding tax treaty requests. Indonesia has been considered successful in maintaining taxation rights on business profits and enforcing the principles of force of attraction income. Meanwhile, regarding the right to tax international shipping businesses, Indonesia must admit the authority of the Organization for Economic Co-operation and Development Model. Regarding the dividends, interest and royalties' policies, Indonesia often plays moderate with a fifty-fifty policy on tariff restrictions.
\end{abstract}

Keywords: Tax Treaty, Policy, Investment.

\section{Introduction}

In the tax law in the jurisdiction of the Republic of Indonesia, which must carry out the mandate of Article 23A of the 1945 Constitution of the Republic of Indonesia (UUD NRI 1945) which reads "Taxes and other levies that are coercive for the purposes of the state are regulated by law", which is to emphasize that tax collection in Indonesia still refers to Article 1 paragraph (3) of the 1945 Constitution which states that the Republic of Indonesia is a state based on law. This means that all matters relating to the taxation rights and obligations of every citizen must be based on law, including statutory regulations.

In practice, the taxation law in Indonesia cannot be separated from its international association, so it requires other instruments besides the law, namely the Double Taxation Avoidance Agreement (P3B) or tax treaty, to regulate each of the rights and obligations between Indonesian taxpayers and taxpayers. Taxpayers whose countries are listed in the tax treaty. However, the efforts of many countries to make tax treaties apart from being a means to prevent international tax evasion as well as to attract foreign investment, investment protection and promotion, and other diplomatic reasons (United Nations, 2014), have not been successful, as is still rampant. problem of tax avoidance and tax evasion of multinational companies (Multinational Enterprise, MNE), especially in the form of base erosion and profit shifting (BEPS). This BEPS problem refers to the erosion of the tax base by exploiting loopholes in the 
applicable laws and regulations (Peng, 2016), to shift profits from jurisdictions that impose higher tax rates to jurisdictions that impose lower tax rates (Hines, 2014), which is certainly very detrimental (OECD, 2015) developing countries.

Several empirical facts have shown how big the tax losses are due to the misuse of tax treaties. One of them is the problem of tax avoidance and tax evasion of multinational companies which are indicated by the Organization for Economic Co-operation and Development (OECD) that have caused losses of around $4 \%$ to $10 \%$ of global corporate income tax (PPh) revenues, or around US\$100 billion. up to US\$240 Billion annually (OECD, 2015). The magnitude of this indication of global income tax losses is in line with the potential loss of tax revenue in Indonesia due to the misuse of tax treaties.

One of them is the findings of the Dutch-based Association of Initiatives and NonGovernmental Organizations (NGOs) from the Netherlands, SOMO, which in its report entitled How the Indonesia-Netherlands Tax Treaty Enables Tax Avoidance stated that the tax treaty between Indonesia and the Netherlands had caused a potential loss of tax potential in Indonesia of Rp. 5 billion in the period from 2010 to 2019. This potential loss of tax revenue is based on cases of tax disputes at the Tax Court and Supreme Court levels that occurred between the government and multinational companies that took advantage of the tax treaty between Indonesia and the Netherlands, whereas many as 25 cases of a total of 27 cases have been won by multinational companies (Pryanka \& Zuraya, 2019).

In addition, there are findings of the Audit Results Report (LHP) of the Supreme Audit Agency of the Republic of Indonesia (BPK, 2015) on the 2014 Central Government Financial Report (LKPP) which reports that Indonesia has a tax treaty with 63 countries in the world, which among others have agreed on PPh rates. on the interest of 5\%-15\% which is used to calculate PPh DTP on interest on SBN issued in the international market.

However, the DGT does not use the tax treaty rate because the final taxpayer who holds the international foreign currency SBN (bondholder) cannot be identified. As a result, in 2013, the calculation of PPh DTP SBN did not match the average tax treaty rate of Rp1.56 trillion. In the 2014 LKPP examination, BPK re-examined the calculation of PPh DTP on international foreign currency SBN interest by considering the average tax treaty rate of $10 \%$. The tariff is taken from the average tax treaty rate from 63 countries, which is between $5 \%-15 \%$. The results of the calculation based on the average tax treaty rate show that State revenues from PPh DTP SBN Foreign Exchange have the potential to be higher at a maximum of Rp.2.36 Trillion (10\% $\mathrm{x}$ Rp.23.59 Trillion).

The juridical gap refers to the tax treaty that is part of the International Agreement, as the gap occurs in the following three main points. First, the tax treaty, which must be based on the mandate of Article 23A of the 1945 Constitution as it has been affirmed that coercive taxes and levies must be based on law, still refers to Article 32A of Law Number 7 of 1983 concerning Income Tax as amended several times, most recently by Law no. 36 of 2008 (PPh Law) which reads "The government has the authority to enter into agreements with the governments of other countries in the context of avoiding double taxation and preventing tax evasion."

The explanation of this article which states that a tax treaty is a special legal instrument (lex specialist) in the context of improving economic and trade relations with other countries, which regulates the taxation rights of each country in order to provide legal certainty and avoid the imposition of double taxation and preventing tax evasion is not in line with the formulation of Article 4 paragraph (2) and Article 18 of Law Number 24 of 2000 concerning International Agreements (International Treaty Law). Article 4 paragraph (2) of the International Treaty Law requires the making of international agreements which must be guided by the national interest and based on the principles of equality, mutual benefit, and taking into account both applicable 
national and international law. Then, Article 18 of the International Treaty Law regulates the termination of International Agreements, meaning that the lex specialist - a tax treaty as regulated in Article 32A of the Law should not apply considering that the tax law does not at all regulate the limits or criteria that are included in the tax treaty category. guidelines for national interests and the principles of equality, mutual benefit, and attention to, and termination of tax treaties.

The focus of the study in this research is to produce a tax treaty concept that provides the greatest prosperity for the people of Indonesia, is fair, and in accordance with the national interest.

\section{Legal Reconstruction}

The understanding of reconstruction (law) that will be carried out in this research is based on the definition in Black's Law Dictionary which states that reconstruction is "the act or process of rebuilding, re-creating, or reorganizing something (an expert in accident reconstruction). Big Indonesian Dictionary (KBBI) defines reconstruction as re-arranging (depicting), and Sinaga and Sinaga's thoughts which emphasize that reconstruction is an action or process to rebuild, recreate or reorganize certain existing models so that they become more ideal. to be used as a solution that prioritizes output and outcome to overcome certain losses.

Legal reconstruction will be carried out on tax treaties in Indonesia, which currently in the terminology of Article 1 point 2 PER-10/PJ/2017 refers to the term P3B, which is an agreement between the Government of Indonesia and the Government of Partner Countries or Partner Jurisdictions in the context of avoiding double taxation and tax evasion prevention. The Black's Law Dictionary defines a treaty as "an agreement formally signed, ratified, or adhered to between two nations or sovereigns; an international agreement concluded between two or more states in written form and governed by international law.

Also termed accord, convention, covenant, declaration, pact (Gardner, 2009)," while Collin (2000) more specifically defines a double tax treaty as "an agreement between two countries that a person living in one country shall not be taxed in both countries. on the income earned in the other country." The definition put forward by Black's Law Dictionary and Collin implies that a tax treaty is an international agreement made between two or more countries that every person (a person) who lives in a country will not be taxed twice on the same income earned in a country. other countries.

\section{Tax Treaty}

Reduction of sources of tax revenue due to the tax treaty cannot be separated from the reciprocal form due to differences in tax rates and the tax treaty partner's tax system. Thus, a tax treaty should be beneficial for each country involved, even though a tax treaty can cause an imbalance in terms of income exchange for one of the tax treaty partner countries (Roin, 1995).

Several functions of the tax treaty, among others, are to promote investment flows that are useful for the economic development of each country, remove tax barriers for cross-border investment, prevent cross-border tax evasion and evasion, encourage development in certain areas, and provide certain political benefits. The justification for each country in carrying out a tax treaty is highly dependent on the country's economic, political and legal situation in relation to potential treaty partner countries (United Nations, 2014).

This is in line with Johnson's study which concludes that tax treaties can lead to large FDI inflows that are expected to spur economic growth through financial development, so that tax treaties should be strengthened as a credible commitment to international tax norms (Johnson, 2018) while still being based on justice in the formation of the law, the scope of which must reach both taxpayers and the tax apparatus themselves (Sinaga, et. al., 2020). 


\section{Research Methods}

This research is normative juridical research, so it is hoped that it can produce an ideal tax treaty conception in Indonesia considering that normative and evaluative propositions occupy a central position in certain moral values, namely justice (Bruggink \& Sidharta, 2015). This is also in line with the fundamentals of this research, which are philosophical and juridical studies, which allow the flow of thought to take the form of prescriptive and evaluative forms. Prescriptive refers to its efforts to obtain suggestions to overcome the problems posed in the research, while evaluative refers to the efforts of this research to assess the application and running provisions.

The stand point of this research is based on the normative view, which views the core relationship in science as the relationship between the subject and the subject, not the relationship between the subject and the object such as the positivism view. This view will ultimately produce inter-subjective knowledge, so that the researcher's stand point must be on an internal perspective, which is close to the symptoms he wants to study as a participant (Mukherjee, 2019).

It is important to understand the phenomena that occur in tax treaties through research that is carried out systematically and then critically analyses problems in order to provide advice to stakeholders, such as the government, legislature, and judiciary with an interest in tax treaties. For this research to be carried out systematically, a research process chart is needed to provide a roadmap with directions for conducting this legal research. There are three general phases in the tax law research process, namely formulation, execution, and analysis (Hair, Page, \& Brunsveld, 2019).

The formulation phase involves defining the substance, creating a research design, combining research materials, which will ultimately produce the desired results. Some of the tasks of this phase are to determine research needs and determine the formulation of the problem, to the stage of designing research. After formulating the research, the implementation phase can begin. In this stage, the researcher actively collects legal information and materials from appropriate sources. Such legal information and materials will be error-checked, coded, and stored in such a way as to allow for comprehensive analysis. Next is the analytical phase, namely the stage of analysing data and legal materials. The first task in the analytical phase includes selecting and applying methods to analyse the data. The results of the analysis refer to the answers to the formulation of the problem.

Data processing techniques in this normative research include inventory, exposure, interpretation, systematization, and evaluation of positive laws related to taxes, treaties, and tax treaties that apply in the jurisdiction of Indonesia or certain countries by providing concepts, categories, theories and theories, classifications, and methods, which answer the existing problem formulation.

\section{Results and Discussion}

\section{Construction of the tax treaty law that has been in effect in Indonesia}

In Article 23A of the 1945 Constitution, which has emphasized that forced taxes and levies must be based on the law, it is explicitly regulated in the tax law order considering that the law is not regulated but in the order of the Director-General of Taxes Regulation Number, PER10/PJ/2017 on the Procedure for the Application of Double Taxation Avoidance Agreement 
explicitly states that the benefit of a tax treaty is a facility in $\mathrm{P} 3 \mathrm{~B}$ which can be in the form of a lower tax rate than the tax rate as stipulated in the Income Tax Law or an exemption from taxation in the source country.

Of course, the wider scope of regulation of the Director-General of Taxes compared to the applicable law shows that there are provisions in the discretionary order that do not adhere to the types and hierarchies of the laws and regulations in force in Indonesia, as referred to in Article 7 of Law Number 12 of 2011 concerning the Establishment of Legislation, which regulates the order from the highest to the lowest are the 1945 Constitution of the Republic of Indonesia, Decree of the People's Consultative Assembly (TAP MPR), Laws/Regulations of Law (Perpu), Government Regulations, Presidential Regulations (Perpres), Provincial and Regency/City Regional Regulations (Perda).

Provisions and Types of Legislation are recognized for their existence and have legal force if they are ordered by higher laws and regulations. One example that the consistency of the tax treaty is state sovereignty has been proven by the United States, where the tax treaty protocol was approved by the United States Senate. Suppose the tax treaty between the United States and Indonesia on December 23, 1996, the United States Senate agreed that the withholding rate on dividends, interest, and royalties on direct investment would be reduced from fifteen to ten percent (Schneidman, et al., 1997).

Second, the position of the super tax treaty shows that after the tax treaty is agreed and issued, each country may not cancel the provisions contained in the tax treaty even though the domestic tax law has been amended or made in the future, or known as "override". This is in stark contrast to the tax laws in the United States, even though it has a different legal system from Indonesia, where the Congress and the Supreme Court have the premise that domestic laws can override tax treaties as part of a sovereign desire. The United States Congress firmly recognizes that tax treaty waivers can occur, and its decision not to include provisions suspending tax treaties demonstrates that Congress intends to enforce its domestic tax laws regardless of the international consequences (Agnew, 1996).

Third, the tax law and international treaty law have not set the ideal tax treaty model in Indonesia. Thousands of tax treaties around the world generally base their models on two models (which are non-binding), namely the Model convention sponsored by the OECD and the United Nations (UN) Model. The PBB model is essentially identical to the OECD model but differs with respect to several important provisions (Rixen \& Schwarz, 2009).

In the Development Law Model, it can be applied to countries and or communities who want to create order and order in their economic law association. This legal model departs from the sociological jurisprudence school pioneered by Roscoe Pound, which explicitly states the law as a tool of social engineering (law as a tool of social engineering). Sociological jurisprudence is also known as the theory of functional jurisprudence, which pays great attention to the functioning of law in society (Rumokoy \& Maramis, 2014).

This theory is expected to be able to function law in dealing with tax treaty challenges that still occur in Indonesia. Pound (1943) emphatically states that although sociological jurisprudence is in line with the sociology of law in terms of the development and development of law, the differences are very clear. Sociology of law processes the development and development from sociology to law, while sociological jurisprudence processes the development and development from historical and philosophical jurisprudence (historical and philosophical jurisprudence) on the use of social sciences, especially sociology, towards a broader and more effective legal science.

The feasibility of sociological jurisprudence can be seen from the task of social engineering to construct and or reconstruct the law in the field of taxation in the face of the ever- 
changing phenomenon of taxpayers. Social engineering must be aimed at 3 (three) interest groups that must be legally protected, namely: 1) public interests, 2) social interests, and 3) personal interests. Public interests include the interests of the state as a legal entity in maintaining its personality and essence, and the interests of the state as the guardian of social interests. Meanwhile, personal interests consist of interests in domestic relations and interests in substance, all of which include physical integrity, freedom of will, privacy, freedom of religion, and opinion (Friedmann, 1990).

Then in Indonesia itself, the theory of functional jurisprudence or sociological jurisprudence was successfully incorporated by Kusumaatmadja (2006) into the Outlines of State Policy (GBHN) in 1973 by changing the notion of law as a tool in sociological jurisprudence into law as an instrument) to renew or build the community, or what is known as the Development Law Model. This legal model begins with Kusumaatmadja's desire to form a modern national law, which is relevant to other legal systems in the world, by prioritizing principles that are generally accepted by nations, without having to leave the original legal principles that are still valid and relevant to modern world life. Such principles and concepts are contained in the 1945 Constitution of the Republic of Indonesia and its Preamble which is a reflection of the Pancasila philosophy. This Development Law Model itself can be concluded by Atmasasmita (2010) in the following 5 (five) core teachings or principles:

First, all developing societies are always characterized by change, and the law functions to ensure that change occurs in an orderly manner. Regular changes, not irregular changes using violence alone, can be assisted by legislation or court decisions, or a combination of both. Second, both change and order (or order) are the initial goals of a developing society, so the law becomes a means (not a tool) that cannot be ignored in the development process. Third, the function of law in society is to maintain order through legal certainty, and also the law (as a social rule) must be able to regulate (help) the process of change in society. Fourth, good law is the law that is in accordance with the living law in society, which of course is also appropriate or is a reflection of the values that apply in that society. Fifth, the implementation of the legal function can only be realized if the law is carried out by power but the power itself must run within the limits of the signs specified in the law.

The use of law as a means to carry out social engineering in dealing with tax treaty challenges in Indonesia is important in a concept of community transformation, because the countries involved in making the tax treaty can use the law consciously to achieve a state of society that makes changes in a conscious way. orderly and orderly (Rahardjo, 2009). The Development Law Model will be the basis for the state so that the various options in the formation of (legal) tax treaties prioritize the interests of the nation and state (Hermawan \& Sinaga, 2020), namely those who should strive to protect the entire Indonesian nation and the entire homeland of Indonesia and to promote public welfare, as mandated by the Fourth Paragraph of the Preamble to the 1945 Constitution of the Republic of Indonesia.

The importance and urgency of legal reconstruction actions in handling tax treaty challenges through the framework of the Development Law Model in Indonesia show that basically a shift in legal thinking is needed. From those who have so far pursued legal certainty through the fulfillment of formal justice as long as it refers to a system that is lex scripta, lex certa, and lex stricta, to a legal certainty that has aspects of material and formal justice that seeks to realize the ideals of general welfare and guarantee The state has implemented tax treaty guidelines as a means of legal certainty and at the same time a means to guide economic development and legal development in an orderly and orderly manner. 


\section{Legal reconstruction in producing an ideal tax treaty model in Indonesia}

A tax treaty, like the tax law, is the highest tax law in a country in terms of international taxation, which is only subject to the constitution. However, tax treaties are not created in the same way as domestic tax laws. The tax law is relatively open by first issuing a draft law (RUU) at the beginning of the process, the discussion of which must go through the legislative and executive powers. Before a bill becomes law, hearings are public and interested parties usually have many opportunities to voice their criticisms and debates.

In contrast to the domestic tax law, the process of making a tax treaty is only based on the negotiation of an agreement between the Ministry of Finance and the Ministry of Foreign Affairs and/or related partners. After the first drafts were exchanged, negotiations took place, either face-to-face or by correspondence. The agreement is reviewed by each relevant government, then initialed, signed and finally published (American Bar Association, Raish, \& Stone, 1993). Specifically in Indonesia, Article 2 of the Law on International Treaties stipulates that the Minister of Foreign Affairs provides political considerations and takes the necessary steps in establishing and ratifying international agreements, in consultation with the House of Representatives (DPR) in matters concerning the public interest.

The special position of a tax treaty in Indonesia cannot be separated from its position as an international agreement, as Article 1 point 1 of the International Treaty Law has defined an international treaty as an agreement, in a certain form and name, which is regulated in international law which is made in writing and gives rise to rights. and obligations in the field of public law. The importance and urgency of legal reconstruction actions in handling tax treaty challenges through the framework of the Development Law Model in Indonesia shows that basically a shift in legal thinking is needed.

From those who have so far pursued legal certainty through the fulfillment of formal justice as long as it refers to a system that is lex scripta, lex certa, and lex stricta, to a legal certainty that has aspects of material and formal justice which seeks to realize the ideals of the general welfare and ensure that The state has implemented tax treaty guidelines as a means of legal certainty as well as a means to guide economic development and legal development in an orderly and orderly manner (American Bar Association, Raish, \& Stone, 1993).

Problems that still arise in the Indonesian tax treaty need progressive legal guidance with the principle that the law does not exist for itself, but for something wider and bigger, namely in dealing with every time there is a problem within and with the law, the law is the one that is reviewed. and repaired (Rahardjo, 2009). Progressive law is a correction of the weakness of the modern legal system which is full of bureaucracy and wants to free itself from the domination of the liberal type of law, so that its main goal is to protect the people towards the ideal of law by rejecting the status-quo, as its credo always refers to "Law is a law". an institution that aims to deliver people to a just, prosperous life and make people happy (Rahardjo, 2009). Progressive law is expected to be continuously in the process of becoming (law as a process, law in the making) in developing and changing Indonesia's tax treaty to the level of legal perfection, whose perfection quality can be verified into justice, welfare, concern for the people and others. -others are better (Rahardjo, 2009).

The guidance of the Progressive Legal Model in supporting law development and orderly and orderly economic development to reconstruct tax treaties that are not in line with the state's objectives is reflected in 2 (two) main characteristics. The first characteristic, as quoted directly from the thoughts of Rahardjo (2008) follows:

"The paradigm in progressive law is, that "law is for humans". This basic premise, optics or belief does not see the law as something central in law, but it is humans who are at the center of the legal cycle. The law revolves around the human being at its center. Law exists for humans, 
not humans for law. If humans are for the law, then humans will always be cultivated, maybe also forced to enter into the schemes that have been made by law. Then the second characteristic asserts that "Progressive law refuses to maintain the status quo in law. Maintaining the status quo gives the effect that the law is the benchmark for all, and humans are for the law, so that such legal methods are in line with positivistic, normative, and legalistic ways (Rahardjo, 2008).

More deeply about the implementation of the progressive legal model in supporting the reconstruction of the prosecutor's authority for mixed military criminal prosecutions, is in line with the opinion of Atmasasmita (2010) which asserts that the model which strongly rejects the analytical jurisprudence tradition is an idea that explores the following 8 (eight) points:

"1) The law rejects the opinion that order only works through the state; 2) Progressive law is aimed at protecting the people towards the ideal of law; 3) The law rejects the status quo and does not want to make the law a technology that has no conscience, but rather a moral institution; 4) Law is an institution that aims to deliver people to a just, prosperous, and happy life; 5) Progressive law is, "pro-people law" and "pro-justice law"; 6) The basic assumption of progressive law is that the law is for humans, not the other way around. In this regard, the law does not exist for itself, but for something wider and greater. So whenever there is a problem in and with the law, it is the law that is reviewed and corrected and not the human being who is forced into the legal system; 7) Law is not an absolute and final institution but is very dependent on how humans see and use it. Humans are the ones who decide; 8) The law is always in the process of becoming (law as a process, law in the making)."

The development law model and the progressive legal model are expected to have a practical side in reconstructing tax treaties in the legal system and the domestic tax law of each country is not necessarily the same. The development law model and the progressive legal model are expected to have the ability to classify and re-establish jurisdictional and taxation matters related to tax treaty core matters, namely Permanent Establishment (PE), interest, dividends, and royalties.

To give the source country taxation jurisdiction over local business operations, the country is entitled to income tax "attributable to" a PE in the source country. A PE is a "permanent place of business" where a company's business is carried on in whole or in part, or it may also arise through the activities of a dependent agent in a jurisdiction that owns and exercises the authority to conclude contracts on behalf of the company. The concept of BUT is based on policy and administrative considerations, where in terms of policy, the right of the source country to the income tax attributable to the BUT will allow for a fair distribution of income between the source country and the country of residence. Of course, this explanation implies that the definition of BUT can vary, especially in the current era of globalization which requires comparative analysis in determining jurisdictions based on websites or internet servers (Reinhold, 2004).

In terms of determining "interest", in general, the source country can impose income tax on the interest that arises at a certain rate. However, many countries are consistent with policies of eliminating source taxes on passive income, such as the United States Model Tax Treaty which sets a zero percent rate. In terms of dividends and royalties, there are several treatments in the tax treaty model. In the case of dividends, generally, the source country can tax dividends at a certain rate, even a much smaller rate or zero percent for shareholdings of at least $25 \%$. Meanwhile, royalty income is generally not taxed by the source country.

However, in certain cases, although a country has the freedom to determine taxes on corporate profits from subsidiaries in its jurisdiction, interest, and royalties paid to the parent company are treated as expenses under the Corporate Taxpayer Income Tax. So to secure some state taxes from this revenue stream, some countries cut taxes on the income of the repatriated 
investment. In addition, they also cut taxes on dividend payments to foreign parties, whose sources of tax deductions are limited by tax treaties (Rixen \& Schwarz, 2012).

\section{Conclusion}

The tax law and the International Treaty Law have not set the ideal Tax treaty Model in Indonesia. Thousands of tax treaties around the world generally base their models on two models (which are basically non-binding), namely the Model convention sponsored by the OECD and the United Nations (UN) Model. In the Development Law Model, it can be applied to countries and or communities who want to create order and order in their economic law association. This legal model departs from the sociological jurisprudence flow, in Indonesia, this theory was incorporated into the 1973 State Policy Guidelines (GBHN) by changing the notion of law as a tool into law as an instrument to renew or build society.

In granting the source country taxation jurisdiction over local business operations, the country is entitled to income tax "attributable to" a Permanent Establishment (BUT) in the source country. A PE is a "permanent place of business" where a company's business is carried on in whole or in part, or it may also arise through the activities of a dependent agent in a jurisdiction that owns and exercises the authority to conclude contracts on behalf of the company. The importance and urgency of legal reconstruction actions in handling tax treaty challenges through the framework of the Development Law Model in Indonesia show that a shift in legal thinking is needed.

From those who have so far pursued legal certainty through the fulfilment of formal justice as long as it refers to a system that is lex scripta, lex certa, and lex stricta, to a legal certainty that has aspects of material and formal justice that seeks to realize the ideals of general welfare and guarantee The state has implemented tax treaty guidelines as a means of legal certainty and at the same time a means to guide economic development and legal development in an orderly and orderly manner.

\section{References}

[1] Adinda Pryanka \& Nidia Zuraya. (2019). "Potensi Pajak Rp390,5 Miliar Hilang Akibat Treaty Shopping.” Republika. tersedia di https://republika.co.id/berita/q212zg383/potensi-pajak-rp3905-miliar-hilang-akibat-ltemgttreaty-shoppingltemgt

[2] Agnew, C. L. (1996). Expatriation, Double Taxation, and Treaty Override: Who Is Eating Crow Now?. The University of Miami Inter-American Law Review, 69-94.

[3] American Bar Association Section of Taxation Committee on U.S. Activities of Foreigners and Tax Treaties, Raish, D., \& Stone, N. (1993). Issues Paper On The Tax Treaty Making Process. The Tax Lawyer, 46(2), 477-506.

[4] Atmasasmita, Romli. (2010). Globalisasi dan Kejahatan Bisnis. Jakarta: Prenada Media.

[5] Atmasasmita, Romli. (2010). Globalisasi dan Kejahatan Bisnis. Jakarta: Prenada Media.

[6] Badan Pembinaan dan Pembinaan Bahasa Kementerian Pendidikan dan Kebudayaan Republik Indonesia. Kamus Besar Bahasa Indonesia versi Digital. tersedia pada: https://kbbi.kemdikbud.go.id/entri/rekonstruksi

[7] Badan Pemeriksa Keuangan Republik Indonesia. (2015). Laporan Hasil Pemeriksaan atas Laporan Keuangan Pemerintah Pusat Tahun 2014 Nomor 74b/LHP/XV/05/2015 tanggal 25 Mei 2015. Jakarta: Badan Pemeriksa Keuangan Republik Indonesia.

[8] Bruggink, J. J., \& Sidharta, B. A. (2015). Refleksi tentang hukum: pengertian-pengertian dasar dalam teori hukum. Citra Aditya Bakti. 
[9] Collin, P. H. (2000). Dictionary of Law. London: Bloomsbury Publishing Plc.

[10] Friedmann W. (1990). Teori dan Filsafat Hukum: Idealisme Filosofis dan Problema Keadilan [penerjemah Muhamad Arifin]. Jakarta: CV. Rajawali.

[11] Gardner, B. A. (2009). Black's Law Dictionary 9th Edition, St. Paul MN: West Publishing Company.

[12] Hair, J. F., Page, M., \& Brunsveld, N. (2019). Essentials of business research methods. Routledge.

[13] Hermawan, Anis W. \& Henry D. P. Sinaga. (2020). "Public Benefit Principle in Regulating ECommerce Tax on Consumer's Location in Indonesia." International Journal of Advanced Science and Technology, Vol. 29, No. 08.

[14] James R. Hines Jr. (2014). "Policy Forum: How Serious is the Problem of Base Erosion and Profit Shifting?." Canadian Tax Journal, Vol. 62, No. 2.

[15] Johnson, A. P. (2018). Global Governance, Tax Treaties, and Credible Commitments. World Affairs, 181(1), 69-98. https://doi.org/10.1177\%2F0043820018776410

[16] Kusumaatmadja, Mochtar. (2006) Konsep-Konsep Hukum Dalam Pembangunan: Kumpulan Karya Tulis. Bandung: PT. Alumni.

[17] Mukherjee, Shyama Prasad. (2019). A Guide to Research Methodology: An Overview of Research Problems, Tasks and Methods. New York: CRC Press.

[18] Organization for Economic Co-operation and Development (OECD). (2015). Explanatory Statement, OECD/G20 Base Erosion and Profit Shifting Project. Tersedia pada: www.oecd.org/tax/bepsexplanatory-statement-2015.pdf.

[19] Peng, W. (2016). Multinational tax base erosion problem of the digital economy. Modern Economy, 7(03), 345.

[20] Pound, Roscoe. (1943). "Sociology of Law and Sociological Jurisprudence." The University of Toronto Law Journal, Vol. 5, No. 1.

[21] Rahardjo, Satjipto. (2008). Biarkan Hukum Mengalir: Catatan Kritis tentang Pergulatan Manusia dan Hukum. Jakarta: Kompas.

[22] Rahardjo, Satjipto. (2009). Hukum dan Perubahan Sosial: Suatu Tinjauan Teoritis serta Pengalaman-Pengalaman di Indonesia. Yogyakarta: Genta Publishing.

[23] Rahardjo, Satjipto. (2009). Hukum Progresif: Sebuah Sintesa Hukum Indonesia. Yogyakarta: Genta Publishing.

[24] Reinhold, R. L. (2004). "Some Things That Multilateral Tax Treaties Might Usefully Do." The Tax Lawyer, Vol. 57, No. 3.

[25] Rixen, T., \& Schwarz, P. (2009). Bargaining over the avoidance of double taxation: Evidence from German tax treaties. Finanzarchiv/Public Finance Analysis, 442-471.

[26] Rixen, T., \& Schwarz, P. (2012). "How effective is the European Union's savings tax directive? Evidence from four EU member states.” JCMS: Journal of Common Market Studies, 50(1), 151-168.

[27] Roin, J. (1995). Rethinking Tax Treaties in a Strategic World with Disparate Tax Systems. Virginia Law Review, 1753-1799.

[28] Rumokoy, D. Albert \& Frans Maramis. (2014). Pengantar Ilmu Hukum. Jakarta: Rajawali Pers.

[29] Schneidman, L., Stone, S., Schaul-Yoder, R., \& Nacamuli, A. (1997). United States Activities of Foreigners and Tax Treaties. The Tax Lawyer, 50(4), 1167-1176.

[30] Sidharta, B. A. (2009). Penelitian Hukum Normatif: Analisis Penelitian Filosofikal dan Dogmatikal. dalam Metode Penelitian Hukum Konstelasi dan Refleksi. Jakarta: Yayasan Obor Indonesia.

[31] Sinaga, Benny R. P., Elvrida N. Sinaga, Leo B. Barus, Reny Y. Sinaga \& Henry D. P. Sinaga. (2020). "Justice Reconception In Establishing Responsive Tax Law in Indonesia: A Rawlsian Perspective." Ayer Journal, Vol. 27, No. 3

[32] Sinaga, Henry D.P. \& Benny R.P. Sinaga. (2018). Rekonstruksi Model-Model Pertanggungjawaban di Bidang Perpajakan dan Kepabeanan. Yogyakarta: Penerbit Kanisius.

[33] United Nations. (2014). Papers on Selected Topics in Negotiation of Tax Treaties fro Developing Countries. New York: United Nations.

[34] United Nations. (2014). Papers on Selected Topics in Negotiation of Tax Treaties fro Developing Countries. New York: United Nations. 